\title{
Effects of different sodium salts and nitrogen sources on the production of 3-hydroxybutyrate and polyhydroxybutyrate by Burkholderia cepacia
}

\author{
Jianfei Wang ${ }^{1} \mathbb{B}$, Jiaqi Huang ${ }^{1,2}$, Huanyu Guo ${ }^{1}$, Shaoming Jiang ${ }^{1}$, Jinyue Qiao ${ }^{1}$, Xingyu Chen ${ }^{1}, Z_{\text {Zxuan }}$ Qu $^{1,3}$, \\ Wanyue Cui ${ }^{1}$ and Shijie Liu' ${ }^{1 *}$
}

\begin{abstract}
The effects of $\mathrm{NaCl}, \mathrm{Na}_{2} \mathrm{SO}_{4}, \mathrm{Na}_{2} \mathrm{HPO}_{4}$, and $\mathrm{Na}_{3} \mathrm{C}_{6} \mathrm{H}_{5} \mathrm{O}_{7}$ on the production of 3-hydroxybutyrate, polyhydroxybutyrate, and by-products by Burkholderia cepacia. Proper addition of $\mathrm{Na}_{3} \mathrm{C}_{6} \mathrm{H}_{5} \mathrm{O}_{7}$ can significantly promote the production of 3-hydroxybutyric acid and polyhydroxybutyrate. The concentration, productivity, and yield of 3-hydroxybutyrate were increased by $48.2 \%, 55.6 \%$, and $48.3 \%$ at $16 \mathrm{mM} \mathrm{Na}_{3} \mathrm{C}_{6} \mathrm{H}_{5} \mathrm{O}_{7}$. The increases of $80.1 \%, 47.1 \%$, and $80.0 \%$ in the concentration, productivity, and yield of polyhydroxybutyrate were observed at $12 \mathrm{mM} \mathrm{Na}_{3} \mathrm{C}_{6} \mathrm{H}_{5} \mathrm{O}_{7}$. $\mathrm{Na}_{2} \mathrm{SO}_{4}$ and $\mathrm{Na}_{2} \mathrm{HPO}_{4}$ also have positive effects on the production capacity of 3-hydroxybutyrate and polyhydroxybutyrate within a certain range of concentration. $\mathrm{NaCl}$ is not conducive to the improvement of fermentation efficiency. Compared with a single nitrogen source, a mixed nitrogen source is more conducive to enhancing the production of 3-hydroxybutyrate and polyhydroxybutyrate.
\end{abstract}

Keywords: 3-Hydroxybutyrate, Polyhydroxybutyrate, Burkholderia cepacia, Sodium salts, Nitrogen source

\section{Introduction}

3-Hydroxybutyrate (3-HB) is an organic monomer with both hydroxyl and carboxyl groups, which is considered an important chemical precursor or intermediate to synthesize other monomers, copolymers, and homopolymers with good performance in the chemical industry (Wang and Liu 2014; Anjum et al. 2016). In addition, 3-HB can be widely used in the chemical industry and pharmaceutical industry due to its unique chiral structure as an important precursor to produce antibiotics, vitamins, and other related products (Ren et al. 2010). Polyhydroxybutyrate (PHB) is a kind of polyhydroxyalkanoate (PHA) with 3-HB as the monomer produced

\footnotetext{
*Correspondence: sliu@esf.edu

${ }^{1}$ Department of Chemical Engineering, SUNY College of Environmental

Science and Forestry, Syracuse, NY 13210, USA

Full list of author information is available at the end of the article
}

during the secondary metabolism of some microorganisms, which has been confirmed to exist in these microorganisms as an important energy storage substance (Koller 2018; Kessler and Witholt 2001). Compared with petroleum-based polymers, PHB has biodegradability and unique mechanical properties, which can be used as an effective substitute for traditional plastics (Aramvash et al. 2018). In the pharmaceutical industry, PHB has become an advanced high-performance medical material due to its good chemical properties and biocompatibility (Koller 2018). The production of various PHAs was estimated to reach $\$ 57,000,000$ in 2019 , and the total market size of PHAs was predicted to reach \$98, 000,000 by 2024 (Sirohi et al. 2021).

The studies on the 3-HB usually focus on different production methods, mainly including chemical synthesis, chemical or enzymatic depolymerization of PHB, and in vivo depolymerization of PHB. The chemical 
synthesis requires a higher level of substrate purity and catalyst performance, which results in increased production costs. Chemical or enzymatic depolymerization of PHB usually requires strict control of process conditions and has a relatively low yield (Wang and Liu 2014). The in vivo depolymerization of PHB can be carried out under mild conditions with a higher yield, and its production efficiency can also be improved more easily by optimizing fermentation conditions and medium components. Therefore, this method has a great development potential, which is of great significance for reducing production costs and technical difficulties. Currently, the biosynthesis of PHB has become a research hotspot. The strains used for PHB synthesis are mainly Bacillus (Bomrungnok et al. 2020), Cupriavidus (Leong et al. 2019), halophilic archaeal strains (Salgaonkar and Bragança 2017), Pseudomonas (Pereira et al. 2021), engineered Saccharomyces cerevisiae (Kocharin and Nielsen 2013), and engineered Escherichia coli (Bhatia et al. 2015). In recent years, Burkholderia species have also been used for PHB production, but the related research is limited.

Burkholderia cepacia (B. cepacia) is a strain that synthesizes $\mathrm{PHB}$ and depolymerizes $\mathrm{PHB}$ into (R)-3-HB simultaneously from various carbon sources, which has high production efficiency, stable yield, and high tolerance to various production inhibitors (Dietrich et al. 2013). The theoretical total yield of $3-\mathrm{HB}$ is $0.770 \mathrm{~g} / \mathrm{g}$ glucose based on Eq. (1):

$$
3 \mathrm{C}_{6} \mathrm{H}_{6} \mathrm{O}_{6} \rightarrow 4 \mathrm{CH}_{3} \mathrm{CH}(\mathrm{OH}) \mathrm{CH}_{2} \mathrm{COOH}+2 \mathrm{CO}_{2}+2 \mathrm{H}_{2} \mathrm{O}
$$

Compared to that of polylactic acid (PLA), the production methods of PHB are significantly different. The PLA is produced by the chemical polymerization of the lactic acid monomer, which is usually obtained by the fermentation process (Wang et al. 2020). However, the PHB is obtained directly from the fermentation process, which is synthesized and accumulated by the metabolism of B. cepacia cells. The 3-HB will also be obtained by the in vivo depolymerization of PHB by further metabolism of $B$. cepacia. Therefore, changes in fermentation conditions will simultaneously affect the production rate and yield of PHB and 3-HB.

The studies on the biosynthesis of $3-\mathrm{HB}$ and $\mathrm{PHB}$ mainly focus on the optimization of fermentation process parameters (Mohd Zain et al. 2021) and the application of cheap carbon sources (Bhatia et al. 2015). In terms of media component analysis and optimization, current research mainly involves the effects of nitrogen source type and $\mathrm{C} / \mathrm{N}$ ratio on the synthesis of $3-\mathrm{HB}$ and PHB (Li et al. 2019). However, other related studies, especially the studies on 3-HB production, are still limited. It has been reported that PHB synthesis and accumulation in cells can be achieved by limiting one or more key nutrients, mainly provided by the anions of the inorganic salt, but controlling these anions at a small amount can promote the synthesis and accumulation of $\mathrm{PHB}$ or promote the depolymerization of PHB into 3-HB (Wang and Liu 2014). In addition, some anions can also promote the production of $\mathrm{PHB}$ and $3-\mathrm{HB}$ by inhibiting cell growth or other metabolic pathways (Azizi et al. 2017). Therefore, the analysis of anion effects and the optimization of anion types and concentrations will have great significance to the production of 3-HB and PHB. The effects of inorganic salts on the extracellular PHB degradation by PHB depolymerase have been reported (Blevins et al. 2018). However, the effect of inorganic salts on the intracellular production of 3-HB and PHB is still rarely studied. In addition, the effects of different nitrogen sources on the production of 3-HB and PHB still need to be further analyzed.

In this study, four types of sodium salts were applied to the production of $3-\mathrm{HB}$ and $\mathrm{PHB}$ by $B$. cepacia cells through the batch fermentation process. The effects of each type of sodium salt on the production of 3-HB, PHB, and by-products were studied at eight levels. The effects of different nitrogen sources on the production of the mentioned products were also studied.

\section{Materials and methods \\ Seed culture preparation}

The B. cepacia ATCC 17759 provided by American Type Culture Collection (ATCC) was stored as freeze-dried cells in a $-80^{\circ} \mathrm{C}$ freezer. Before using for PHB and 3-HB production, the $B$. cepacia cells were activated in the seed culture medium for $48 \mathrm{~h}$ on a shaker at $220 \mathrm{rpm}$ and $30{ }^{\circ} \mathrm{C}$. The seed culture medium was composed of $5.0 \mathrm{~g} / \mathrm{L}$ peptone and $5.0 \mathrm{~g} / \mathrm{L}$ beef extract.

\section{Batch fermentation}

The batch fermentation was conducted in 1.0-L New Brunswick bioreactors with a working volume of $800 \mathrm{ml}$. The carbon source was $54 \mathrm{~g} / \mathrm{L}$ glucose. The nitrogen sources were $1 \mathrm{~g} / \mathrm{L}$ peptone. The environment of key ions for PHB synthesis was created by $20 \mathrm{mg} / \mathrm{L} \mathrm{CaCl}_{2}, 80 \mathrm{mg} / \mathrm{L}$ $\mathrm{MgSO}_{4}, 50 \mathrm{mg} / \mathrm{L} \mathrm{ZnSO}{ }_{4}, 30 \mathrm{mg} / \mathrm{L}\left(\mathrm{NH}_{4}\right)_{5}\left[\mathrm{Fe}\left(\mathrm{C}_{6} \mathrm{H}_{4} \mathrm{O}_{7}\right)_{2}\right]$, and $1 \mathrm{~g} / \mathrm{L} \quad \mathrm{K}_{2} \mathrm{HPO}_{4}$. The composition was modified based on the study of Wang and Liu (2014) and Rodrigues et al. (2019) to adapt to the different substrate and nitrogen source. The sodium salts with different anions at a specific concentration were added to the fermentation medium before fermentation to study the effects of the type and initial concentration of sodium salts on PHB and 3-HB production by B. cepacia cells (Table 1). The $\mathrm{pH}$ was automatically controlled at 7.0 by adding $5 \mathrm{M} \mathrm{NaOH}$ solution. The temperature was maintained at $28^{\circ} \mathrm{C}$ by heat jacket. The aeration and stirring speed were 
Table 1 The type and concentration level of sodium salts

\begin{tabular}{llllllll}
\hline Sodium salt & \multicolumn{2}{l}{ Concentration level $(\mathbf{m M})$} & & & \\
\cline { 2 - 8 } & $\mathbf{1}$ (Control) & $\mathbf{2}$ & $\mathbf{3}$ & $\mathbf{4}$ & $\mathbf{5}$ & $\mathbf{6}$ & $\mathbf{7}$ \\
\hline $\mathrm{NaCl}$ & 0 & 10 & 20 & 30 & 40 & 50 & $\mathbf{8}$ \\
$\mathrm{Na}_{2} \mathrm{SO}_{4}$ & 0 & 4 & 8 & 12 & 16 & 20 & 24 \\
$\mathrm{Na}_{2} \mathrm{HPO}_{4}$ & 0 & 4 & 8 & 12 & 16 & 20 & 24 \\
$\mathrm{Na}_{3} \mathrm{C}_{6} \mathrm{H}_{5} \mathrm{O}_{7}$ & 0 & 4 & 8 & 12 & 16 & 20 & 24 \\
\hline
\end{tabular}

maintained at $50 \mathrm{ml} / \mathrm{min}$ and $200 \mathrm{rpm}$, respectively. The fermentation period was determined based on the time when the concentration of $3-\mathrm{HB}$ reached the highest concentration. The effects of different nitrogen sources on the synthesis of various products were studied with single nitrogen sources and mixed nitrogen sources. The single nitrogen sources included peptone, yeast extract, urea, and $\left(\mathrm{NH}_{4}\right)_{2} \mathrm{SO}_{4}$. The mixed nitrogen sources were composed of two single nitrogen sources with a weight ratio of 1:1. All single nitrogen sources and mixed nitrogen sources were maintained at $1 \mathrm{~g} / \mathrm{L}$, and other fermentation conditions remained the same.

\section{Determination of cell biomass concentration}

The concentration of cell biomass was calculated based on the optical density (OD) at a wavelength of $600 \mathrm{~nm}$ measured by an OD scanner (BugLab, CA, USA). A calibration curve showing the linear relationship between concentration of cell biomass and OD value was applied.

\section{Determination of 3-HB, lactate, and acetate}

The concentrations of $3-\mathrm{HB}$, lactate, and acetate were determined by $1 \mathrm{H}$ nuclear magnetic resonance (NMR) spectroscopy based on the method provided by Wang and Liu (2014). The NMR samples were composed of $0.1 \mathrm{ml}$ internal standard, $0.4 \mathrm{ml} \mathrm{D}_{2} \mathrm{O}$, and $0.5 \mathrm{ml}$ fermentation broth sample. The internal standard solution was prepared by dissolving $4.2 \%(\mathrm{w} / \mathrm{w})$ glucosamine, $0.2 \%$ $(\mathrm{w} / \mathrm{w})$ trimethylamine, and $0.1 \%(\mathrm{w} / \mathrm{w})$ trimethylsilyl propionate, and it was stored in $-10{ }^{\circ} \mathrm{C}$ freezer after preparation. The product concentration was calculated with a linear calibration curve between the mass concentration and the area of the corresponding peak shown on the NMR spectrum.

\section{Determination of PHB}

The harvested cell biomass was centrifuged at $4000 \times \mathrm{g}$ for $10 \mathrm{~min}$ and subsequently freeze-dried. The freezedried cells were subsequently dispersed by the mixture solution consisting of $2 \mathrm{ml}$ sodium hypochlorite and $2 \mathrm{ml}$ chloroform at $60{ }^{\circ} \mathrm{C}$ for $24 \mathrm{~h}$. The PHB dissolved in the organic phase was obtained by separating the aqueous phase with cell debris after centrifugation at $4000 \times \mathrm{g}$ for $20 \mathrm{~min}$. The PHB solution was poured into a $10 \mathrm{~cm}$ glass petri dish and subsequently placed in a fume hood to evaporate the organic solvent for $10 \mathrm{~h}$ to recycle the PHB film. Samples for $1 \mathrm{H}$ NMR quantification were prepared and analyzed based on the method provided by Jan et al. (1996). Samples were prepared by dissolving the PHB film into $1 \mathrm{ml} \mathrm{CDCl}_{3}$. The $1 \%$ methanol and $1 \%$ benzene were also added to the sample solution as the internal standard.

\section{Statistical analysis}

The experimental data were shown as "mean value \pm standard deviation" based on triplicate runs of the experiment. The data were analyzed based on a T-test by Minitab 18 with a $95 \%$ level of significance.

\section{Results and discussion \\ Effects of $\mathrm{NaCl}$ on the production of $3-\mathrm{HB}, \mathrm{PHB}$, and by-products}

The results of 3-HB production at different levels of $\mathrm{NaCl}$ concentration are shown in Fig. 1a. When there was no variable salt added, the concentration of 3-HB obtained from batch fermentation was $15.22 \mathrm{~g} / \mathrm{L}$. The concentration of 3-HB did not show significant difference when the $\mathrm{NaCl}$ concentration was between 0 and $40 \mathrm{mM}$. However, when $\mathrm{NaCl}$ concentration reached $50 \mathrm{mM}$, the 3-HB concentration was $5.5 \%$ lower than the control group. The final 3-HB concentration of $11.45 \mathrm{~g} / \mathrm{L}$ was obtained at $\mathrm{NaCl}$ concentration of $70 \mathrm{mM}$, which was $24.8 \%$ lower than the control group.

The effects of different $\mathrm{NaCl}$ concentration levels on the PHB production are shown in Fig. 1b. The PHB concentration of $3.21 \mathrm{~g} / \mathrm{L}$ with a PHB content of $52.8 \%$ was obtained with the control group. The highest concentration and content were obtained at $\mathrm{NaCl}$ concentration of $30 \mathrm{mM}$ as $4.84 \mathrm{~g} / \mathrm{L}$ and $68.9 \%$, respectively, which were $50.8 \%$ and $30.5 \%$ higher than the control group, respectively. At $\mathrm{NaCl}$ concentration of $60 \mathrm{mM}$, the PHB concentration was not significantly different from the control group, but the PHB content was significantly higher. The 


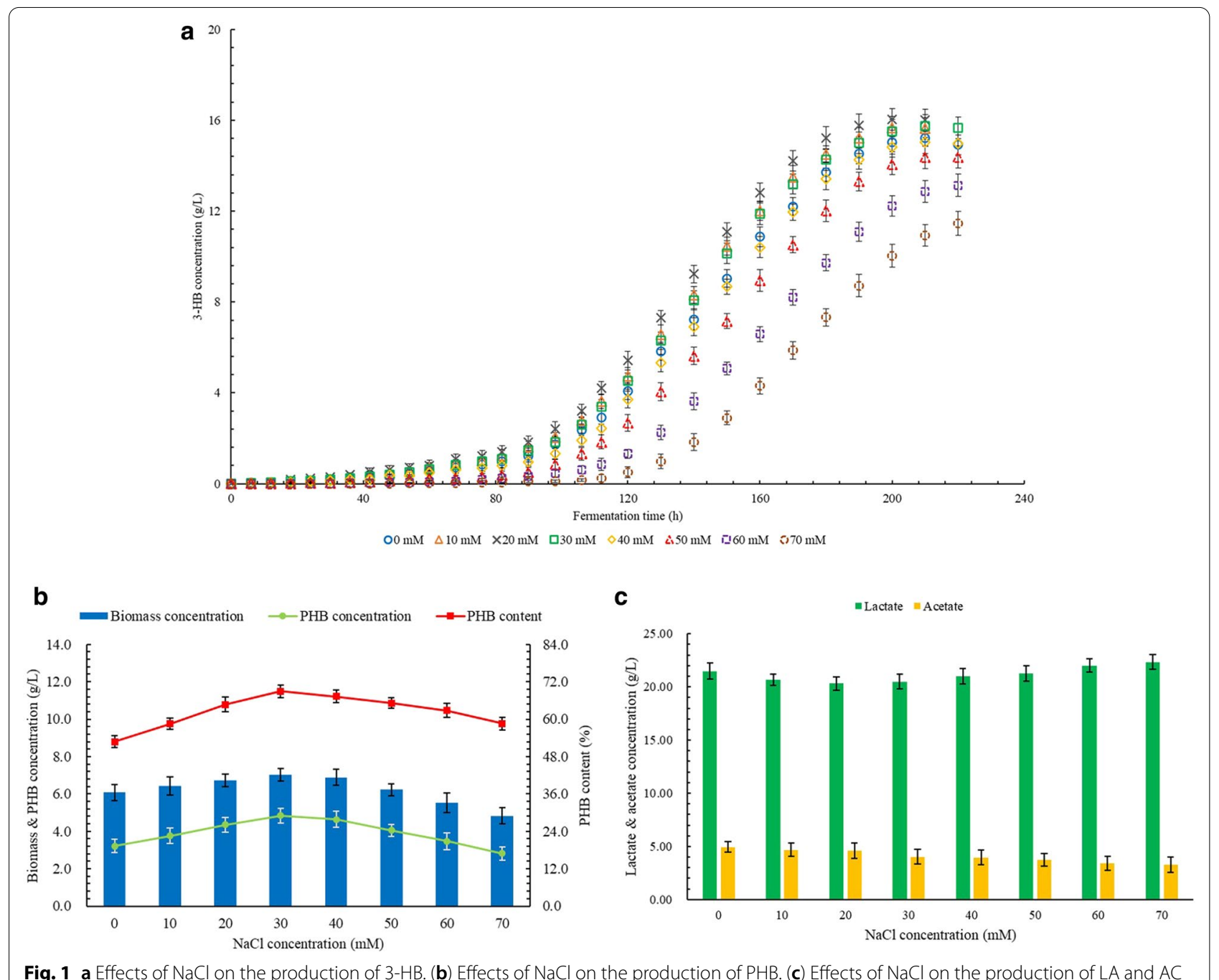

PHB content of $58.6 \%$ at $70 \mathrm{mM} \mathrm{NaCl}$ was still $11.0 \%$ higher than the control group with insignificant difference of PHB concentration.

Lactate (LA) and acetate (AC) were regarded as byproducts in the production of 3-HB and PHB by B. cepacia. The LA and AC concentrations of the control group were $21.48 \mathrm{~g} / \mathrm{L}$ and $4.94 \mathrm{~g} / \mathrm{L}$, respectively. As shown in Fig. 1c, the LA concentration did not change significantly in the range of $\mathrm{NaCl}$ concentration. The $\mathrm{AC}$ concentration showed a downward trend with the increase in $\mathrm{NaCl}$ concentration. The lowest $\mathrm{AC}$ concentration was obtained as $3.27 \mathrm{~g} / \mathrm{L}$ at $\mathrm{NaCl}$ concentration of $70 \mathrm{mM}$, which was $33.8 \%$ lower than the control group.

Table 2 shows the yield and productivity of $3-\mathrm{HB}$ and $\mathrm{PHB}$ at different levels of $\mathrm{NaCl}$ concentration. The highest productivity of $3-\mathrm{HB}$ was obtained at $20 \mathrm{mM}$ $\mathrm{NaCl}$, which was $10.6 \%$ higher than the control group. However, the highest yield of $3-\mathrm{HB}$ was obtained at
Table 2 The productivity and yield of 3-HB and PHB at different $\mathrm{NaCl}$ concentrations

\begin{tabular}{llllll}
\hline $\begin{array}{lllll}\text { Concentration, } \\
\mathbf{m M}\end{array}$ & $\begin{array}{l}\text { Productivity, } \\
\mathbf{g} /(\mathbf{L} \times \mathbf{h})\end{array}$ & & $\begin{array}{l}\text { Yield, } \\
\mathbf{g} / \mathbf{g} \text { glucose }\end{array}$ & \\
\cline { 2 - 3 } \cline { 5 - 6 } & $\mathbf{3 - H B}$ & $\mathbf{H H B}$ & $\mathbf{3}-\mathbf{H B}$ & $\mathbf{P H B}$ \\
\hline 0 & $0.073 \pm 0.002$ & $0.015 \pm 0.002$ & $0.298 \pm 0.005$ & $0.063 \pm 0.006$ \\
10 & $0.078 \pm 0.003$ & $0.019 \pm 0.002$ & $0.303 \pm 0.007$ & $0.074 \pm 0.007$ \\
20 & $0.080 \pm 0.002$ & $0.022 \pm 0.002$ & $0.307 \pm 0.006$ & $0.085 \pm 0.007$ \\
30 & $0.075 \pm 0.002$ & $0.023 \pm 0.002$ & $0.311 \pm 0.007$ & $0.095 \pm 0.007$ \\
40 & $0.072 \pm 0.002$ & $0.022 \pm 0.002$ & $0.297 \pm 0.007$ & $0.092 \pm 0.008$ \\
50 & $0.065 \pm 0.002$ & $0.018 \pm 0.001$ & $0.289 \pm 0.007$ & $0.080 \pm 0.006$ \\
60 & $0.060 \pm 0.002$ & $0.016 \pm 0.002$ & $0.258 \pm 0.007$ & $0.068 \pm 0.008$ \\
70 & $0.052 \pm 0.002$ & $0.013 \pm 0.002$ & $0.225 \pm 0.008$ & $0.056 \pm 0.007$ \\
\hline
\end{tabular}

$30 \mathrm{mM} \mathrm{NaCl}$, which was $4.1 \%$ higher than the control group. Both highest productivity and yield of PHB were 
obtained at $30 \mathrm{mM} \mathrm{NaCl}$, which were $41.8 \%$ and $33.6 \%$ higher than the control group, respectively.

Some studies have reported that the proper concentration of $\mathrm{NaCl}$ will promote biosynthesis of $\mathrm{PHB}$ (Thapa et al. 2018; Azizi et al. 2017). The effects of $\mathrm{NaCl}$ at different concentrations on cell growth and metabolism were mainly related to the change in osmotic pressure. Appropriate addition of $\mathrm{NaCl}$ can improve the osmotic pressure environment and increase the overall metabolic efficiency of cells, thereby simultaneously promoting the production of $\mathrm{PHB}$ and 3-HB (Wood 2015). It has also been pointed out that the promotion of the decomposition of PHB to produce 3-HB may be due to greater energy demand to cope with changes in osmotic pressure (Rodríguez-Contreras et al. 2016). With the increase in the $\mathrm{NaCl}$ concentration, the osmotic pressure increases, which leads to the dehydration of cells. However, dehydration provides more space for the accumulation of PHB. Therefore, the efficient synthesis and accumulation of PHB at relatively higher $\mathrm{NaCl}$ concentrations is regarded as the process to replace water to maintain the osmotic pressure of cells (Azizi et al. 2017).

When the $\mathrm{NaCl}$ concentration is further increased, a higher degree of cell dehydration occurs, and the inhibitory effect of chloride ions on cell growth and PHB synthesis begins to manifest, resulting in reduced levels of cell growth, PHB synthesis, and 3-HB production. However, due to the requirement to maintain the osmotic pressure of cells, the accumulation level of PHB under high $\mathrm{NaCl}$ concentration is still high. It explains why the PHB content of cells at $70 \mathrm{mM} \mathrm{NaCl}$ is still higher than that of the control group. Under the appropriate $\mathrm{NaCl}$ concentration, the metabolic pathway of PHB synthesis and decomposition are more active, so more substrates are converted into intermediate products, such as pyruvate and acetyl-CoA, and subsequently flow to the metabolic pathway of $\mathrm{PHB}$ and $3-\mathrm{HB}$ production, rather than the synthesis of LA and AC. As the osmotic pressure rises due to the further increase of the $\mathrm{NaCl}$ concentration, although the PHB content is still maintained at a high level, the PHB concentration and synthesis efficiency decrease significantly, which also leads to a reduction in the yield and productivity of 3-HB. In addition, due to more energy demand to cope with the negative effects of high osmotic pressure on cells, more 3-HB is reused, thereby resulting in a reduction in concentration and yield of 3-HB. However, due to the decline in the overall cell metabolism, the level of LA production did not increase significantly. The decrease in $\mathrm{AC}$ concentration might be due to the preferential flow of substrate to other pathways under the increased concentration of $\mathrm{NaCl}$.

\section{Effects of $\mathrm{Na}_{2} \mathrm{SO}_{4}$ on the production of 3-HB, PHB, and by-products}

The effect of different $\mathrm{Na}_{2} \mathrm{SO}_{4}$ concentrations on 3- $\mathrm{HB}$ production is shown in Fig. 2a. With the increase in $\mathrm{Na}_{2} \mathrm{SO}_{4}$ concentration from 0 to $12 \mathrm{mM}$, the final 3- $\mathrm{HB}$ concentration increased and reached $18.98 \mathrm{~g} / \mathrm{L}$ as the highest value, which was $24.7 \%$ higher than the control group. When the $\mathrm{Na}_{2} \mathrm{SO}_{4}$ concentration reached $24 \mathrm{mM}$, the concentration and of $3-\mathrm{HB}$ was $11.3 \%$ lower than the highest value but still $17.6 \%$ higher than the control group. The lowest final 3-HB concentration of $14.42 \mathrm{~g} / \mathrm{L}$ was obtained at $28 \mathrm{mM} \mathrm{Na}_{2} \mathrm{SO}_{4}$, which was $5.3 \%$ lower than the control group.

As shown in Fig. 2b, both concentration and content of PHB show a parabolic trend with the changes in $\mathrm{Na}_{2} \mathrm{SO}_{4}$ concentration. Both highest PHB concentration of $4.36 \mathrm{~g} / \mathrm{L}$ and highest PHB content of $62.1 \%$ were obtained at $12 \mathrm{mM} \mathrm{Na}_{2} \mathrm{SO}_{4}$, which were $35.8 \%$ and $17.6 \%$ than the control group, respectively. However, the differences in the concentration and content of PHB between 8 and $12 \mathrm{mM} \mathrm{Na}_{2} \mathrm{SO}_{4}$ were not significantly different. As the further increase in $\mathrm{Na}_{2} \mathrm{SO}_{4}$ concentration, the concentration and content of PHB decreased fast. When the $\mathrm{Na}_{2} \mathrm{SO}_{4}$ concentration reached $24 \mathrm{mM}$, the PHB content was significantly lower than the control group, but the PHB concentration did not show a significant difference. The lowest concentration and content of PHB were obtained at $28 \mathrm{mM} \mathrm{Na}_{2} \mathrm{SO}_{4}$ as $5.4 \mathrm{~g} / \mathrm{L}$ and $39.3 \mathrm{~g} / \mathrm{L}$, which were $11.2 \%$ and $34.4 \%$ lower than the control group.

The effects of $\mathrm{Na}_{2} \mathrm{SO}_{4}$ concentration on the concentrations of by-products are shown in Fig. 2c. As the $\mathrm{Na}_{2} \mathrm{SO}_{4}$ concentration increased from 0 to $16 \mathrm{mM}$, the LA concentration decreased fast, and the lowest LA concentration was obtained as $14.91 \mathrm{~g} / \mathrm{L}$, which was $30.6 \%$ lower than the control group. With the further increase in $\mathrm{Na}_{2} \mathrm{SO}_{4}$ concentration, the LA concentration increased gradually, but the LA concentration of $16.54 \mathrm{~g} / \mathrm{L}$ was still 23.0\% lower than the control group. The $\mathrm{AC}$ concentrations did not significantly change between $\mathrm{Na}_{2} \mathrm{SO}_{4}$ concentrations of 0 to $16 \mathrm{mM}$. However, the $\mathrm{AC}$ concentration further increased with the increase in $\mathrm{Na}_{2} \mathrm{SO}_{4}$ concentration, and the highest $\mathrm{AC}$ concentration of $6.94 \mathrm{~g} / \mathrm{L}$ was obtained at $28 \mathrm{mM} \mathrm{Na} \mathrm{SO}_{4}$, which was $40.5 \%$ higher than the control group.

As shown in Table 3, the highest 3-HB productivity was obtained at $16 \mathrm{mM} \mathrm{Na}_{2} \mathrm{SO}_{4}$, which was $28.4 \%$ higher than the control group. The highest $3-\mathrm{HB}$ yield was obtained at $12 \mathrm{mM} \mathrm{Na}_{2} \mathrm{SO}_{4}$, which was $24.7 \%$ higher than the control group. Both the highest productivity and yield of PHB were obtained at $12 \mathrm{mM} \mathrm{Na}_{2} \mathrm{SO}_{4}$, and both were $35.9 \%$ higher than the control group. 


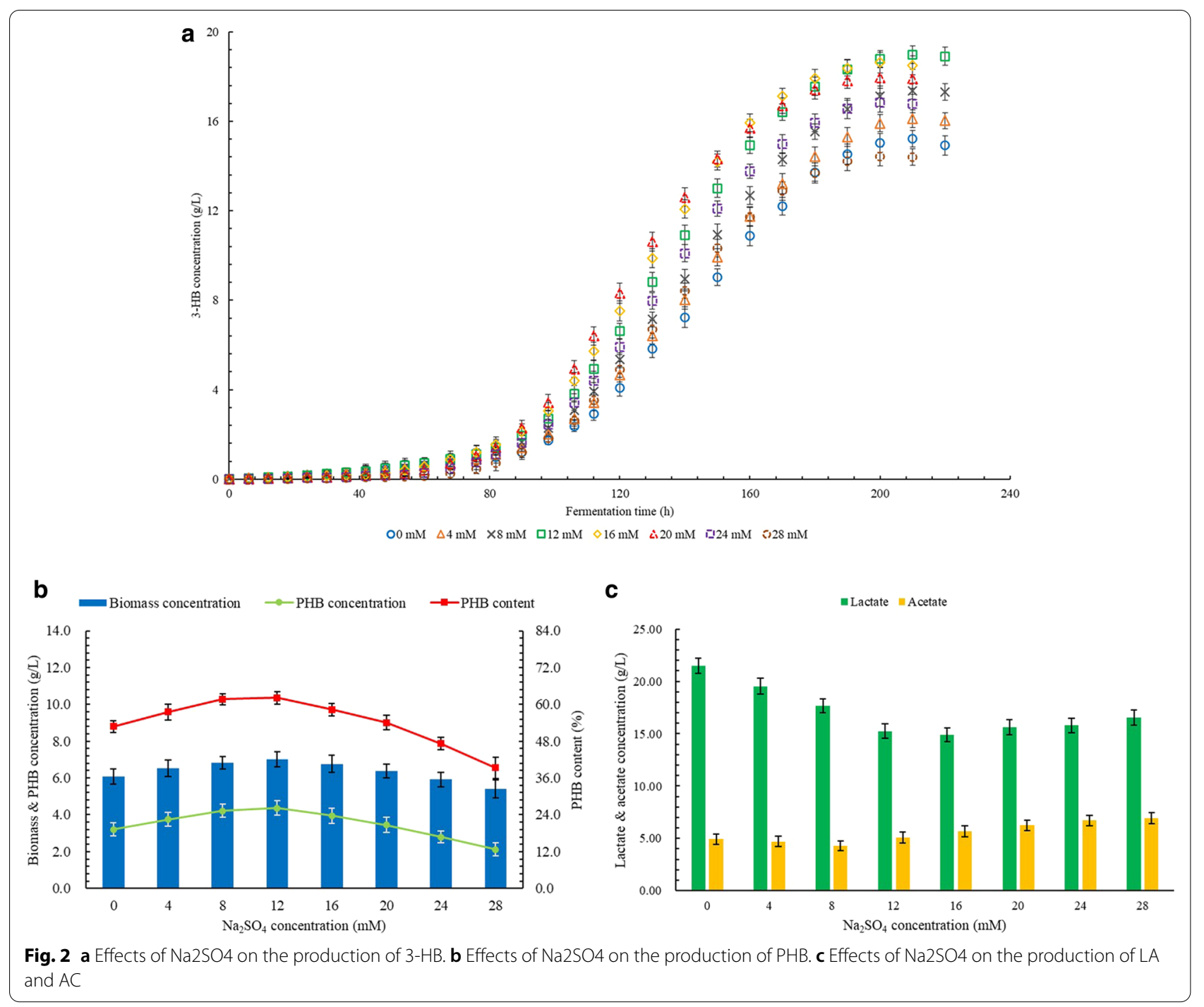

Table 3 The productivity and yield of 3-HB and PHB at different $\mathrm{Na}_{2} \mathrm{SO}_{4}$ concentrations

\begin{tabular}{llllll}
\hline $\begin{array}{l}\text { Concentration, } \\
\mathbf{m M}\end{array}$ & $\begin{array}{l}\text { Productivity, } \\
\mathbf{g} / \mathbf{(} \times \mathbf{h})\end{array}$ & \multicolumn{3}{l}{$\begin{array}{l}\text { Yield, } \\
\mathbf{g} / \mathbf{g} \text { glucose }\end{array}$} \\
\cline { 2 - 3 } \cline { 5 - 6 } & $\mathbf{3 - H B}$ & PHB & $\mathbf{3}-\mathbf{H B}$ & \multicolumn{1}{l}{ PHB } \\
\hline 0 & $0.073 \pm 0.002$ & $0.015 \pm 0.002$ & $0.298 \pm 0.005$ & $0.063 \pm 0.006$ \\
4 & $0.077 \pm 0.002$ & $0.018 \pm 0.002$ & $0.316 \pm 0.005$ & $0.074 \pm 0.007$ \\
8 & $0.083 \pm 0.002$ & $0.020 \pm 0.002$ & $0.340 \pm 0.005$ & $0.083 \pm 0.006$ \\
12 & $0.091 \pm 0.002$ & $0.021 \pm 0.002$ & $0.372 \pm 0.005$ & $0.086 \pm 0.007$ \\
16 & $0.093 \pm 0.002$ & $0.020 \pm 0.002$ & $0.365 \pm 0.005$ & $0.077 \pm 0.008$ \\
20 & $0.090 \pm 0.002$ & $0.017 \pm 0.002$ & $0.352 \pm 0.006$ & $0.068 \pm 0.007$ \\
24 & $0.084 \pm 0.002$ & $0.014 \pm 0.003$ & $0.330 \pm 0.006$ & $0.055 \pm 0.006$ \\
28 & $0.072 \pm 0.002$ & $0.011 \pm 0.002$ & $0.283 \pm 0.006$ & $0.042 \pm 0.007$ \\
\hline
\end{tabular}

At present, studies on the production of $\mathrm{PHB}$ and 3- $\mathrm{HB}$ with $\mathrm{Na}_{2} \mathrm{SO}_{4}$ is still limited. However, the positive effect of $\mathrm{Na}_{2} \mathrm{SO}_{4}$ on PHB synthesis has been confirmed
(Ramezani et al. 2015). For the growth and metabolism of cells, $\mathrm{SO}_{4}{ }^{2-}$ is usually used as a nutrient ion to provide the necessary sulfur for the synthesis of some essential amino acids (Yadav et al. 2017). Therefore, $\mathrm{SO}_{4}{ }^{2-}$ is a key nutritional factor that promotes cell growth and reproduction. Appropriate addition of $\mathrm{Na}_{2} \mathrm{SO}_{4}$ is beneficial to increase the overall metabolic rate of cells, which promotes both synthesis and degradation efficiency of PHB, thereby leading to simultaneous increases in the concentration, yield, and productivity of $3-\mathrm{HB}$ and PHB. This might be due to the participation of $\mathrm{SO}_{4}{ }^{2-}$ in the synthesis of amino acids for CoA-SH production. CoA-SH is further converted into acetyl-CoA rapidly under a high $\mathrm{C} / \mathrm{N}$ ratio, which improves the efficiency of related redox reactions in cells, thereby increasing the production rate of intermediate or final products in various metabolic pathways (Doi et al. 1989). Under the effects of a relatively lower concentration of $\mathrm{Na}_{2} \mathrm{SO}_{4}$, more pyruvate is 
converted into acetyl-CoA, and subsequently flows to the PHB synthesis pathway and the tricarboxylic acid (TCA) cycle instead of the LA synthesis pathway, which leads to a decrease in LA concentration. The decrease in AC concentration may also be due to more acetyl-CoA flowing into other metabolic pathways. The higher overall metabolism of cells also leads to a higher cell growth rate, so the higher cell density is also an important reason for higher overall $\mathrm{PHB}$ accumulation and 3-HB production. In addition, a proper concentration of $\mathrm{SO}_{4}{ }^{2-}$ can promote the uptake of nitrogen sources by cells, and some amino acids can be broken down into acetyl-CoA as the precursor of PHB (Uchino et al. 2007). It may also lead to increased production of $\mathrm{PHB}$ and 3-HB. With the further increase of $\mathrm{Na}_{2} \mathrm{SO}_{4}$ concentration, cell growth is significantly promoted, which leads to the difficulty of PHB production and accumulation due to the negative effect of a higher level of CoA-SH (Alcântara et al. 2020). In the early stage of fermentation, the metabolic pathways related to cell growth become more active, which leads to the weakening of the PHB synthesis pathway. This may be the reason for the lower 3-HB concentration at a higher concentration in the early fermentation stage. In the middle stage of fermentation, the synthesis and decomposition of PHB became the main process, which may be because the cell growth rate decreased significantly due to the consumption of nitrogen sources. However, the presence of $\mathrm{SO}_{4}{ }^{2-}$ still promotes the decomposition of $\mathrm{PHB}$, resulting in a significant increase in the 3-HB production at a higher cell density. The increase in LA concentration is also caused by higher cell density. The increase in AC concentration might be because $3-\mathrm{HB}$ is consumed as a substrate to regenerate acetyl-CoA and flows to the AC synthesis pathway subsequently, which is also related to the higher level of CoA-SH synthesis. Although the production efficiency of 3-HB has been significantly improved in the middle stage of fermentation under a higher $\mathrm{Na}_{2} \mathrm{SO}_{4}$ concentration, the concentration of 3- $\mathrm{HB}$ is still lower than that under lower levels of $\mathrm{Na}_{2} \mathrm{SO}_{4}$ concentration, which is mainly caused by the consumption of more glucose and even 3-HB by other metabolic pathways.

\section{Effects of $\mathrm{Na}_{2} \mathrm{HPO}_{4}$ on the production of 3-HB, PHB, and by-products}

The results of 3-HB production affected by the different $\mathrm{Na}_{2} \mathrm{HPO}_{4}$ concentrations are shown in Fig. 3a. The increased concentration of 3-HB was observed with the increased $\mathrm{Na}_{2} \mathrm{HPO}_{4}$ concentration from 0 to $20 \mathrm{mM}$. The highest final concentration of 3-HB was obtained as $18.82 \mathrm{~g} / \mathrm{L}$, which was $23.7 \%$ than the control group. As the $\mathrm{Na}_{2} \mathrm{HPO}_{4}$ concentration further increased, the 3- $\mathrm{HB}$ concentration decreased sharply. At the $\mathrm{Na}_{2} \mathrm{HPO}_{4}$ concentration of $24 \mathrm{mM}$, the production rate of $3-\mathrm{HB}$ was still maintained at a high level, but the concentration of $3-\mathrm{HB}$ at the end of the fermentation period was significantly lower even than that at $12 \mathrm{mM} \mathrm{Na}_{2} \mathrm{HPO}_{4}$. However, the concentration of 3-HB was significantly higher than the control group. The lowest 3-HB concentration of $13.52 \mathrm{~g} / \mathrm{L}$ was obtained at $28 \mathrm{mM} \mathrm{Na}_{2} \mathrm{HPO}_{4}$, which was $11.2 \%$ lower than the control group.

The effects of different $\mathrm{Na}_{2} \mathrm{HPO}_{4}$ concentrations on PHB production are shown in Fig. 3b. With the increase in $\mathrm{Na}_{2} \mathrm{HPO}_{4}$ concentration from 0 to $16 \mathrm{mM}$, the PHB concentration increased at a relatively stable rate. The highest PHB concentration was obtained as $4.74 \mathrm{~g} / \mathrm{L}$, which was $47.7 \%$ higher than the control group. The $\mathrm{PHB}$ content also increased with the proper increase in $\mathrm{Na}_{2} \mathrm{HPO}_{4}$ concentration, and the highest PHB content was obtained at $12 \mathrm{mM} \mathrm{Na}_{2} \mathrm{HPO}_{4}$ as $64.3 \%$, which was $21.8 \%$ higher than the control group. As the $\mathrm{Na}_{2} \mathrm{HPO}_{4}$ concentration further increased from 16 to $28 \mathrm{mM}$, both concentration and content of PHB decreased fast. When the $\mathrm{Na}_{2} \mathrm{HPO}_{4}$ concentration reached $20 \mathrm{mM}$, both concentration and content of PHB were significantly lower than the highest values but still significantly higher than the control group. The lowest PHB content was obtained at $28 \mathrm{mM} \mathrm{Na} \mathrm{HPO}_{4}$, which was $15.2 \%$ lower than the control group. However, the PHB concentration at $28 \mathrm{mM} \mathrm{Na}_{2} \mathrm{HPO}_{4}$ was not significantly different from the control group.

As shown in Fig. 3c, the LA concentration decreased as the $\mathrm{Na}_{2} \mathrm{HPO}_{4}$ concentration increased from 0 to $20 \mathrm{mM}$. The lowest LA concentration was obtained as $14.63 \mathrm{~g} / \mathrm{L}$, which was $31.9 \%$ lower than the control group. With the further increase in $\mathrm{Na}_{2} \mathrm{HPO}_{4}$ concentration from 20 to $28 \mathrm{mM}$, the LA concentration did not significantly change. No significant difference of AC concentration was observed at $\mathrm{Na}_{2} \mathrm{HPO}_{4}$ concentrations between 0 to $20 \mathrm{mM}$. However, the $\mathrm{AC}$ concentration increased significantly as the $\mathrm{Na}_{2} \mathrm{HPO}_{4}$ concentration further increased. The highest $\mathrm{AC}$ concentration was obtained at $28 \mathrm{mM}$ as $8.08 \mathrm{~g} / \mathrm{L}$, which was $63.6 \%$ higher than the control group.

The fermentation performance of $B$. cepacia on the production of 3-HB and PHB is shown in Table 4. Both highest productivity and highest yield of $3-\mathrm{HB}$ were obtained at $20 \mathrm{mM} \mathrm{Na} \mathrm{HPO}_{4}$, which were $36.7 \%$ and $23.7 \%$ higher than the control group. Both highest productivity and highest yield of PHB were obtained at $16 \mathrm{mM} \mathrm{Na}_{2} \mathrm{HPO}_{4}$, which were $54.9 \%$ and $47.9 \%$ higher than the control group.

During the fermentation process, the $\mathrm{Na}_{2} \mathrm{HPO}_{4}$ can provide essential phosphorus for cell growth and metabolism, which is usually utilized as the important substrate for the synthesis of adenosine triphosphate (ATP) and nicotinamide adenine dinucleotide phosphate (NADPH) (Freches and Lemos 2017). At present, many studies have 


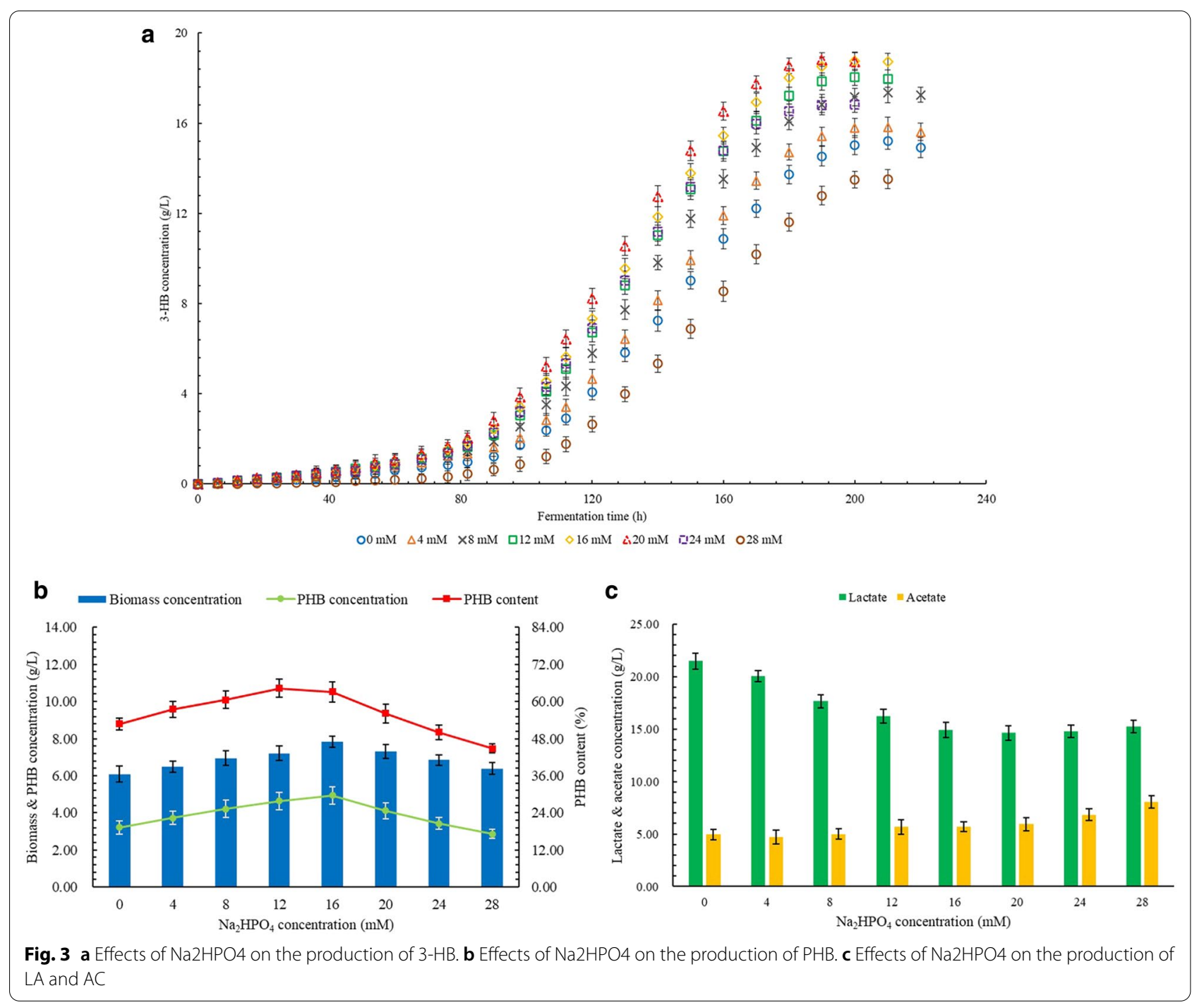

Table 4 The productivity and yield of 3-HB and PHB at different $\mathrm{Na}_{2} \mathrm{HPO}_{4}$ concentrations

\begin{tabular}{|c|c|c|c|c|}
\hline \multirow[t]{2}{*}{$\begin{array}{l}\text { Concentration, } \\
\mathrm{mM}\end{array}$} & \multicolumn{2}{|l|}{$\begin{array}{l}\text { Productivity, } \\
g /(L \times h)\end{array}$} & \multicolumn{2}{|l|}{$\begin{array}{l}\text { Yield, } \\
\text { g/g glucose }\end{array}$} \\
\hline & $3-H B$ & PHB & 3-HB & PHB \\
\hline 0 & $0.073 \pm 0.002$ & $0.015 \pm 0.002$ & $0.298 \pm 0.005$ & $0.063 \pm 0.006$ \\
\hline 4 & $0.075 \pm 0.002$ & $0.018 \pm 0.002$ & $0.310 \pm 0.006$ & $0.073 \pm 0.006$ \\
\hline 8 & $0.083 \pm 0.002$ & $0.020 \pm 0.002$ & $0.340 \pm 0.006$ & $0.083 \pm 0.008$ \\
\hline 12 & $0.090 \pm 0.002$ & $0.023 \pm 0.003$ & $0.354 \pm 0.005$ & $0.091 \pm 0.009$ \\
\hline 16 & $0.094 \pm 0.002$ & $0.024 \pm 0.002$ & $0.368 \pm 0.005$ & $0.093 \pm 0.008$ \\
\hline 20 & $0.099 \pm 0.001$ & $0.022 \pm 0.002$ & $0.369 \pm 0.004$ & $0.081 \pm 0.008$ \\
\hline 24 & $0.084 \pm 0.002$ & $0.017 \pm 0.002$ & $0.330 \pm 0.005$ & $0.067 \pm 0.007$ \\
\hline 28 & $0.065 \pm 0.002$ & $0.014 \pm 0.001$ & $0.265 \pm 0.006$ & $0.056 \pm 0.004$ \\
\hline
\end{tabular}

pointed out that the limitation of phosphorus has a positive effect on the synthesis and accumulation of PHB.
However, the positive effect of proper $\mathrm{Na}_{2} \mathrm{HPO}_{4}$ concentration on PHB synthesis under the nitrogen source limitation has been reported (Moreno et al. 2015). It has been confirmed that NADPH is a key substance in the PHB synthesis process (Kessler and Witholt 2001). The increase in the concentration of NADPH will inhibit the activity of citrate synthase, thereby promoting the flow of acetyl-CoA to the PHB synthesis pathway instead of the TCA cycle. In the PHB synthesis pathway, the substrate produced by $\mathrm{PHB}$ is 3-hydroxybutyrate-CoA, which is generated by the conversion of acetoacetyl-CoA. The conversion of hydroxybutyrate-CoA to acetoacetyl-CoA requires the consumption of NADPH (Wang et al. 2019). Therefore, a high level of NADPH concentration can effectively promote the synthesis and accumulation of PHB. Appropriate addition of $\mathrm{Na}_{2} \mathrm{HPO}_{4}$ can promote the synthesis of NADPH by providing essential phosphorus, thereby improving the yield and production efficiency of 
PHB. In addition, the appropriate addition of $\mathrm{Na}_{2} \mathrm{HPO}_{4}$ will promote the synthesis of ATP, which improves the uptake efficiency of the carbon source, thereby increasing the efficiency of PHB synthesis (Lai and Lan 2021). The increase in 3-HB concentration and production efficiency is also due to the promotion of the overall cell metabolism caused by the increased level of ATP synthesis promotes, thereby simultaneously stimulating the decomposition of PHB. As the concentration of $\mathrm{Na}_{2} \mathrm{HPO}_{4}$ increased, a higher phosphorus concentration results in an increase in the size of the total ATP pool, which significantly promotes cell growth instead of PHB synthesis (García et al. 2021). The increase in cell growth activity promotes the decomposition of $\mathrm{PHB}$, which leads to an increase in the concentration of 3-HB. Higher phosphorus concentrations will also lead to an increase in the level of intracellular $\mathrm{NADP}^{+}$concentration, resulting in a lower PHB production efficiency due to a lower ratio of NADPH and $\mathrm{NADP}^{+}$(García et al. 2018). Therefore, higher concentrations of $\mathrm{Na}_{2} \mathrm{HPO}_{4}$ have a negative effect on the accumulation of PHB. In addition, a higher concentration of phosphorus promotes the conversion of acetyl-CoA to acetyl-P as a substrate, and the acetyl$\mathrm{P}$ can be further converted into acetate by the catalysis of acetate kinase (Park et al. 2019). It explains the reason for an increase in acetate concentration with the increase in $\mathrm{Na}_{2} \mathrm{HPO}_{4}$ concentration. The further increased phosphorus concentration leads to a higher cell growth activity and lower level of NADPH synthesis, which resulted in a further decrease in the production efficiency of PHB (Dalsasso et al. 2019). The decrease in PHB production resulted in a decrease in 3-HB concentration and production efficiency. The decrease in 3-HB concentration is also caused by more $3-\mathrm{HB}$ consumption for acetyl-CoA regeneration to produce acetate.

\section{Effects of $\mathrm{Na}_{3} \mathrm{C}_{6} \mathrm{H}_{5} \mathrm{O}_{7}$ on the production of 3-HB, PHB, and by-products}

The effect of different $\mathrm{Na}_{3} \mathrm{C}_{6} \mathrm{H}_{5} \mathrm{O}_{7}$ concentrations on the production of 3-HB is shown in Fig. 4a. The proper increase in $\mathrm{Na}_{3} \mathrm{C}_{6} \mathrm{H}_{5} \mathrm{O}_{7}$ concentration led to an increase in 3-HB production. The highest $3-\mathrm{HB}$ concentration of $22.56 \mathrm{~g} / \mathrm{L}$ was obtained at $16 \mathrm{mM} \mathrm{Na}_{3} \mathrm{C}_{6} \mathrm{H}_{5} \mathrm{O}_{7}$, which was $48.2 \%$ higher than the control group. When the $\mathrm{Na}_{3} \mathrm{C}_{6} \mathrm{H}_{5} \mathrm{O}_{7}$ concentration increased to $20 \mathrm{mM}$, the 3-HB concentration at the end of the fermentation period was lower than that at $16 \mathrm{mM}$, but the production rate of 3 - $\mathrm{HB}$ in a certain period was higher than that at $20 \mathrm{mM}$ $\mathrm{Na}_{3} \mathrm{C}_{6} \mathrm{H}_{5} \mathrm{O}_{7}$. As the $\mathrm{Na}_{3} \mathrm{C}_{6} \mathrm{H}_{5} \mathrm{O}_{7}$ concentration increased to $24 \mathrm{mM}$, the production rate of $3-\mathrm{HB}$ at the middle stage of the fermentation period was still maintained at a high level, but the final concentration of 3-HB significantly decreased. The production rate and concentration of 3- $\mathrm{HB}$ at $28 \mathrm{mM} \mathrm{Na}_{3} \mathrm{C}_{6} \mathrm{H}_{5} \mathrm{O}_{7}$ further decreased, but the 3 - $\mathrm{HB}$ concentration of $18.37 \mathrm{~g} / \mathrm{L}$ was still $20.7 \%$ higher than the control group.

The results of $\mathrm{PHB}$ production at different $\mathrm{Na}_{3} \mathrm{C}_{6} \mathrm{H}_{5} \mathrm{O}_{7}$ concentrations are shown in Fig. 4b. With the increase in $\mathrm{Na}_{3} \mathrm{C}_{6} \mathrm{H}_{5} \mathrm{O}_{7}$ concentration, the concentration and content of $\mathrm{PHB}$ increased significantly. The highest concentration and content of PHB were obtained at $12 \mathrm{mM} \mathrm{Na}_{3} \mathrm{C}_{6} \mathrm{H}_{5} \mathrm{O}_{7}$ as $5.78 \mathrm{~g} / \mathrm{L}$ and $71.3 \%$, respectively, which were $80.1 \%$ and $35.0 \%$ higher than the control group. As the $\mathrm{Na}_{3} \mathrm{C}_{6} \mathrm{H}_{5} \mathrm{O}_{7}$ concentration further increased, the concentration and content of PHB decreased slowly. The concentration and content of PHB at $28 \mathrm{mM} \mathrm{Na}_{3} \mathrm{C}_{6} \mathrm{H}_{5} \mathrm{O}_{7}$ were $3.98 \mathrm{~g} / \mathrm{L}$ and $59.3 \%$, respectively, which were still $24.0 \%$ and $12.3 \%$ higher than the control group.

The production of by-products affected by different levels of $\mathrm{Na}_{3} \mathrm{C}_{6} \mathrm{H}_{5} \mathrm{O}_{7}$ concentration is shown in Fig. 4c. As the $\mathrm{Na}_{3} \mathrm{C}_{6} \mathrm{H}_{5} \mathrm{O}_{7}$ concentration increased properly, the concentrations of LA and AC decreased significantly. The lowest LA concentration of $12.61 \mathrm{~g} / \mathrm{L}$ was obtained at $16 \mathrm{mM} \mathrm{Na}_{3} \mathrm{C}_{6} \mathrm{H}_{5} \mathrm{O}_{7}$, which was $41.3 \%$ lower than the control group. The lowest $\mathrm{AC}$ concentration was obtained at $8 \mathrm{mM} \mathrm{Na}_{3} \mathrm{C}_{6} \mathrm{H}_{5} \mathrm{O}_{7}$ as $4.07 \mathrm{~g} / \mathrm{L}$, which was $17.6 \%$ lower than the control group. The further increase in $\mathrm{Na}_{3} \mathrm{C}_{6} \mathrm{H}_{5} \mathrm{O}_{7}$ concentration resulted in increased concentrations of LA and AC. At the $\mathrm{Na}_{3} \mathrm{C}_{6} \mathrm{H}_{5} \mathrm{O}_{7}$ concentration of $28 \mathrm{mM}$, the LA concentration was $16.56 \mathrm{~g} / \mathrm{L}$, which was still $22.9 \%$ lower than the control group. However, the $\mathrm{AC}$ concentration at $28 \mathrm{mM} \mathrm{Na}_{3} \mathrm{C}_{6} \mathrm{H}_{5} \mathrm{O}_{7}$ was $8.36 \mathrm{~g} / \mathrm{L}$, which was $69.6 \%$ higher than the control group.

Table 5 shows the productivity and yield of $3-\mathrm{HB}$ and PHB affected by different levels on $\mathrm{Na}_{3} \mathrm{C}_{6} \mathrm{H}_{5} \mathrm{O}_{7}$ concentration. Both highest productivity and highest yield of 3 - $\mathrm{HB}$ were obtained at $16 \mathrm{mM} \mathrm{Na}_{3} \mathrm{C}_{6} \mathrm{H}_{5} \mathrm{O}_{7}$, which were $55.6 \%$ and $48.3 \%$ higher than the control group. Both highest productivity and highest yield of PHB were obtained at $12 \mathrm{mM} \mathrm{Na}_{3} \mathrm{C}_{6} \mathrm{H}_{5} \mathrm{O}_{7}$, which were $47.1 \%$ and $80.0 \%$ higher than the control group. The productivity and yield of $3-\mathrm{HB}$ and $\mathrm{PHB}$ at $28 \mathrm{mM}$ were all higher than the control group.

Citrate is an important intermediate in the TCA cycle, which is generated from acetyl-CoA by the catalysis of citrate synthase. $\mathrm{Na}_{3} \mathrm{C}_{6} \mathrm{H}_{5} \mathrm{O}_{7}$ can provide $\mathrm{C}_{6} \mathrm{H}_{5} \mathrm{O}_{7}{ }^{3-}$ to participate in cell metabolism, thereby regulating cell growth and metabolite synthesis. At present, the positive effect of $\mathrm{Na}_{3} \mathrm{C}_{6} \mathrm{H}_{5} \mathrm{O}_{7}$ on PHB synthesis has been reported, but its related research is still limited (Samantaray and Mallick 2012). The addition of citrate can effectively inhibit the activity of citrate synthase. Therefore, more acetyl-CoA flows into the PHB synthesis pathway to participate in the production of $\mathrm{PHB}$ and $3-\mathrm{HB}$. It may be the main reason for the improvement of $\mathrm{PHB}$ and 3-HB production at a suitable $\mathrm{Na}_{3} \mathrm{C}_{6} \mathrm{H}_{5} \mathrm{O}_{7}$ concentration. 


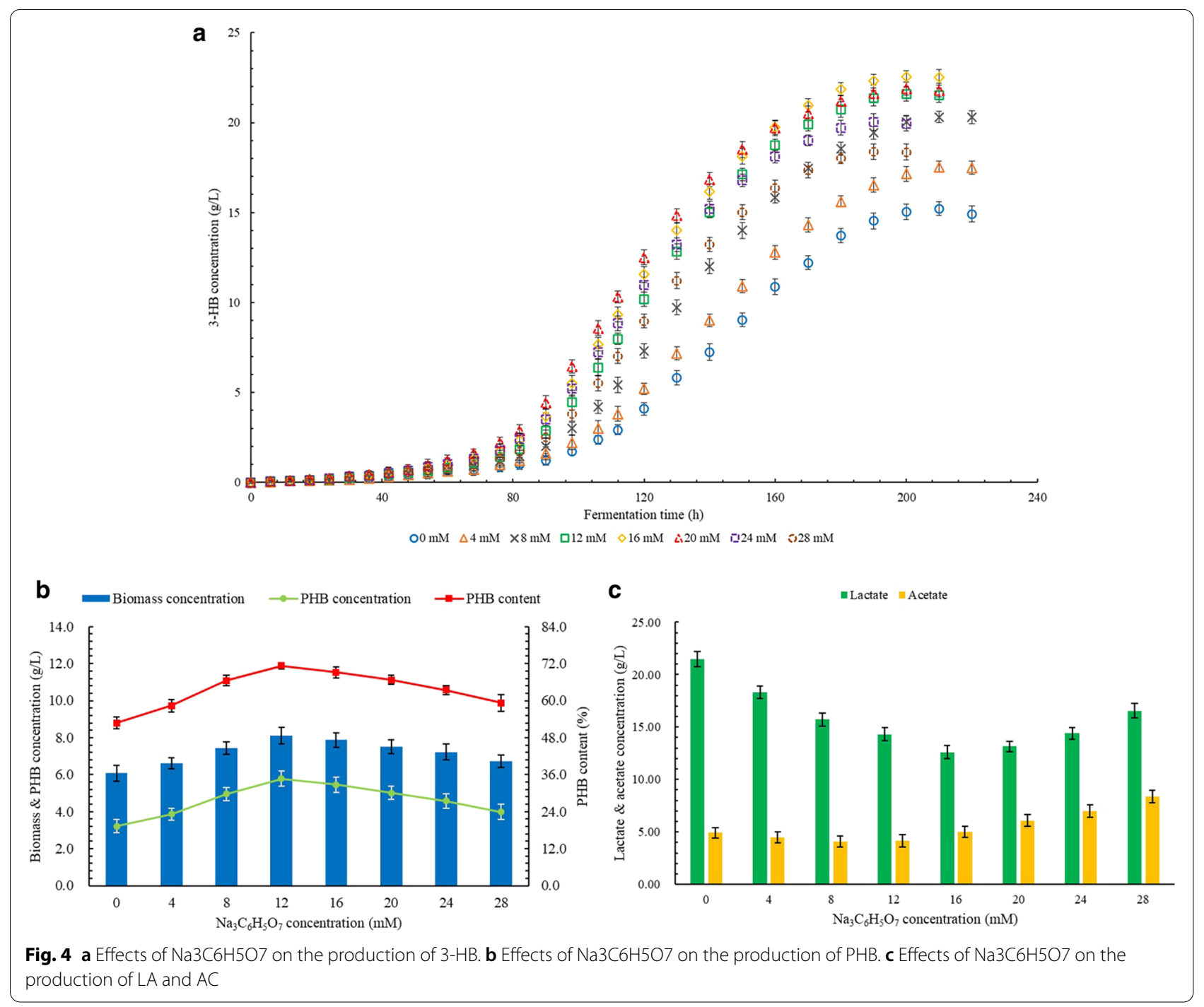

Table 5 The productivity and yield of 3-HB and PHB at different $\mathrm{Na}_{3} \mathrm{C}_{6} \mathrm{H}_{5} \mathrm{O}_{7}$ concentrations

\begin{tabular}{|c|c|c|c|c|}
\hline \multirow[t]{2}{*}{$\begin{array}{l}\text { Concentration, } \\
\mathrm{mM}\end{array}$} & \multicolumn{2}{|l|}{$\begin{array}{l}\text { Productivity, } \\
g /(L \times h)\end{array}$} & \multicolumn{2}{|l|}{$\begin{array}{l}\text { Yield, } \\
\text { g/g glucose }\end{array}$} \\
\hline & $3-\mathrm{HB}$ & PHB & 3-HB & PHB \\
\hline 0 & $0.073 \pm 0.002$ & $0.015 \pm 0.002$ & $0.298 \pm 0.005$ & $0.063 \pm 0.006$ \\
\hline 4 & $0.084 \pm 0.002$ & $0.018 \pm 0.001$ & $0.344 \pm 0.004$ & $0.076 \pm 0.006$ \\
\hline 8 & $0.097 \pm 0.002$ & $0.024 \pm 0.002$ & $0.398 \pm 0.004$ & $0.097 \pm 0.006$ \\
\hline 12 & $0.108 \pm 0.002$ & $0.029 \pm 0.002$ & $0.423 \pm 0.004$ & $0.113 \pm 0.007$ \\
\hline 16 & $0.113 \pm 0.002$ & $0.027 \pm 0.002$ & $0.445 \pm 0.004$ & $0.107 \pm 0.007$ \\
\hline 20 & $0.110 \pm 0.002$ & $0.025 \pm 0.002$ & $0.429 \pm 0.004$ & $0.098 \pm 0.006$ \\
\hline 24 & $0.106 \pm 0.003$ & $0.024 \pm 0.002$ & $0.393 \pm 0.005$ & $0.090 \pm 0.007$ \\
\hline 28 & $0.097 \pm 0.002$ & $0.021 \pm 0.002$ & $0.360 \pm 0.005$ & $0.078 \pm 0.007$ \\
\hline
\end{tabular}

In addition, studies have reported the inhibitory effect of $\mathrm{Na}_{3} \mathrm{C}_{6} \mathrm{H}_{5} \mathrm{O}_{7}$ on the Embden-Meyerhof-Parnas (EMP) pathway, which is resulted from the decrease in phosphofructokinase activity caused by the chelation of $\mathrm{Na}_{3} \mathrm{C}_{6} \mathrm{H}_{5} \mathrm{O}_{7}$ and magnesium ions (Chen et al. 2010). It leads to more glucose flowing into the pentose phosphate pathway in the form of glucose-6-phosphate, thereby promoting the synthesis of NADPH. The increase in the production level of NADPH also promotes the synthesis and accumulation of PHB. The inhibition of the EMP pathway leads to a decrease in the overall pyruvate synthesis level, but the increase in the NADPH synthesis level promotes the conversion of pyruvate into acetyl-CoA and further flows into the PHB synthesis pathway, which leads to a reduction in the pyruvate flowing into the LA synthesis pathway. This may explain the decrease in LA concentration with the appropriate increase in the $\mathrm{Na}_{3} \mathrm{C}_{6} \mathrm{H}_{5} \mathrm{O}_{7}$ concentration. A higher concentration of $\mathrm{Na}_{3} \mathrm{C}_{6} \mathrm{H}_{5} \mathrm{O}_{7}$ caused a significant increase in the concentration of LA and $\mathrm{AC}$ and a decrease in the concentration of PHB. 
However, within a certain range of $\mathrm{Na}_{3} \mathrm{C}_{6} \mathrm{H}_{5} \mathrm{O}_{7}$ concentration, the degradation of $\mathrm{PHB}$ was promoted, which led to a rapid increase in the concentration of 3-HB. This may be because sodium citrate not only directly affects the activity of specific enzymes in multiple metabolic pathways, but also indirectly affects the overall efficiency of cell growth and metabolism by changing the osmotic pressure of the fermentation environment (Samantaray and Mallick 2012). The specific mechanism needs to be further studied. However, citrate can be used as a carbon source to participate in cell metabolism, which improves the ratio of carbon and nitrogen in the fermentation medium, thereby weakening the negative effects of high concentrations of sodium citrate on the production of 3-HB and PHB to a certain extent.

\section{Effects of nitrogen sources on the production of 3-HB, PHB, and by-products}

The production of various products affected by different types of nitrogen sources is shown in Table 6. Compared to that under the condition of the single nitrogen sources, a higher production capacity of $3-\mathrm{HB}$ and $\mathrm{PHB}$ can be obtained under the condition of the mixed nitrogen sources. In addition, the production of the two byproducts is more effectively reduced with the addition of mixed nitrogen sources. The highest production capacity of 3-HB was obtained under the mixed nitrogen source of yeast extract and ammonium sulfate (AS), while the highest production capacity of PHB was obtained under the mixed nitrogen source of yeast extract and urea. Both lowest production capacities of $3-\mathrm{HB}$ and $\mathrm{PHB}$ were obtained under the single nitrogen source of AS. The net cell growth using different nitrogen sources is shown in Fig. 5. Compared to the medium without yeast extract, a higher net cell concentration and a shorter lag phase can be observed in the medium containing yeast extract. The highest activity of cell growth was also observed when yeast extract was combined with urea. It indicated that a proper increase in cell concentration effectively enhance the production of both PHB and 3-HB.

Compared to other single nitrogen sources, the highest production capacity of PHB and 3-HB was obtained when yeast extract was used. As a complex nitrogen source, yeast extract contain various nutrients and promoters for cell growth and metabolism, which might have a positive effect on 3-HB and PHB production (Sharma et al. 2017). As another type of complex nitrogen source, peptone can still maintain the production capacity of 3-HB and PHB at a relatively high level, but its effect is weaker than that of yeast extract. It might be because the composition in yeast extract is more easily taken up and utilized by B. cepacia cells. Urea is a type of organic nitrogen source with a smaller molecular size and stronger polarity, which can be efficiently used by cells (Dañez et al. 2020). Therefore, it can be also regarded as a suitable single nitrogen source for 3- $\mathrm{HB}$ and PHB production. As a type of inorganic nitrogen source, AS has been widely used for PHB production (El-Nahrawy et al. 2018). However, since AS exists in the form of ions carrying charges in the fermentation medium, it has a relatively lower efficiency of uptake and utilization by cells compared to organic nitrogen sources. It might explain the reason for a lower production capacity of $\mathrm{PHB}$ and $3-\mathrm{HB}$ when using $\mathrm{AS}$ as the nitrogen source in this study. At present, studies have reported the positive effects of mixed nitrogen sources on the synthesis of PHB (Sharma et al. 2017). Therefore, the choice of nitrogen source can be modified based on specific strains, substrates, and fermentation conditions. An appropriate increase in the proportion

Table 6 The production of 3-HB, PHB, and by-products under the condition of different nitrogen sources

\begin{tabular}{|c|c|c|c|c|c|c|c|c|c|}
\hline Type & $\begin{array}{l}\text { 3-HB } \\
\text { concentration, } \\
\text { g/L }\end{array}$ & $\begin{array}{l}\text { 3-HB } \\
\text { productivity, } \\
g /(L \times h)\end{array}$ & $\begin{array}{l}\text { 3-HB yield, } \\
\text { g/g glucose }\end{array}$ & $\begin{array}{l}\text { PHB } \\
\text { concentration, } \\
\text { g/L }\end{array}$ & $\begin{array}{l}\text { PHB } \\
\text { content, } \\
\%\end{array}$ & $\begin{array}{l}\text { PHB } \\
\text { productivity, } \\
g /(L \times h)\end{array}$ & $\begin{array}{l}\text { PHB yield, } \\
\text { g/g glucose }\end{array}$ & $\begin{array}{l}\text { LA } \\
\text { concentration, } \\
\text { g/L }\end{array}$ & $\begin{array}{l}A C \\
\text { concentration, } \\
\mathrm{g} / \mathrm{L}\end{array}$ \\
\hline $\begin{array}{l}\text { Peptone (con- } \\
\text { trol) }\end{array}$ & $15.22 \pm 0.38$ & $0.073 \pm 0.002$ & $0.298 \pm 0.005$ & $3.21 \pm 0.35$ & $54.4 \pm 1.9$ & $0.015 \pm 0.002$ & $0.063 \pm 0.006$ & $21.48 \pm 0.74$ & $4.94 \pm 0.49$ \\
\hline Yeast extract & $15.89 \pm 0.53$ & $0.076 \pm 0.003$ & $0.312 \pm 0.007$ & $3.67 \pm 0.29$ & $55.2 \pm 1.7$ & $0.018 \pm 0.002$ & $0.074 \pm 0.007$ & $21.76 \pm 0.68$ & $5.42 \pm 0.56$ \\
\hline Urea & $15.57 \pm 0.57$ & $0.074 \pm 0.003$ & $0.305 \pm 0.008$ & $3.04 \pm 0.32$ & $53.6 \pm 2.3$ & $0.015 \pm 0.002$ & $0.061 \pm 0.006$ & $21.08 \pm 0.81$ & $5.01 \pm 0.42$ \\
\hline AS & $14.63 \pm 0.47$ & $0.070 \pm 0.002$ & $0.287 \pm 0.007$ & $2.30 \pm 0.36$ & $48.3 \pm 2.1$ & $0.011 \pm 0.002$ & $0.045 \pm 0.007$ & $20.53 \pm 0.82$ & $4.90 \pm 0.47$ \\
\hline $\begin{array}{l}\text { Peptone + Yeast } \\
\text { extract }\end{array}$ & $16.35 \pm 0.53$ & $0.078 \pm 0.003$ & $0.321 \pm 0.007$ & $3.79 \pm 0.39$ & $55.5 \pm 2.1$ & $0.017 \pm 0.002$ & $0.070 \pm 0.008$ & $18.91 \pm 0.65$ & $4.86 \pm 0.51$ \\
\hline Peptone + urea & $16.91 \pm 0.55$ & $0.081 \pm 0.003$ & $0.332 \pm 0.007$ & $3.85 \pm 0.41$ & $57.9 \pm 2.5$ & $0.018 \pm 0.002$ & $0.075 \pm 0.008$ & $19.32 \pm 0.71$ & $4.03 \pm 0.58$ \\
\hline Peptone + AS & $17.02 \pm 0.39$ & $0.081 \pm 0.00 \mathrm{~s} 2$ & $0.334 \pm 0.005$ & $3.53 \pm 0.39$ & $56.4 \pm 1.7$ & $0.017 \pm 0.002$ & $0.069 \pm 0.007$ & $20.12 \pm 0.80$ & $4.45 \pm 0.39$ \\
\hline $\begin{array}{l}\text { Yeast } \\
\text { extract + urea }\end{array}$ & $17.16 \pm 0.42$ & $0.082 \pm 0.002$ & $0.337 \pm 0.005$ & $4.68 \pm 0.30$ & $59.2 \pm 2.4$ & $0.022 \pm 0.002$ & $0.091 \pm 0.006$ & $18.36 \pm 0.87$ & $3.87 \pm 0.45$ \\
\hline $\begin{array}{l}\text { Yeast } \\
\text { extract + AS }\end{array}$ & $17.34 \pm 0.47$ & $0.083 \pm 0.002$ & $0.340 \pm 0.006$ & $3.74 \pm 0.38$ & $56.2 \pm 2.8$ & $0.018 \pm 0.002$ & $0.073 \pm 0.007$ & $19.51 \pm 0.79$ & $4.23 \pm 0.53$ \\
\hline
\end{tabular}




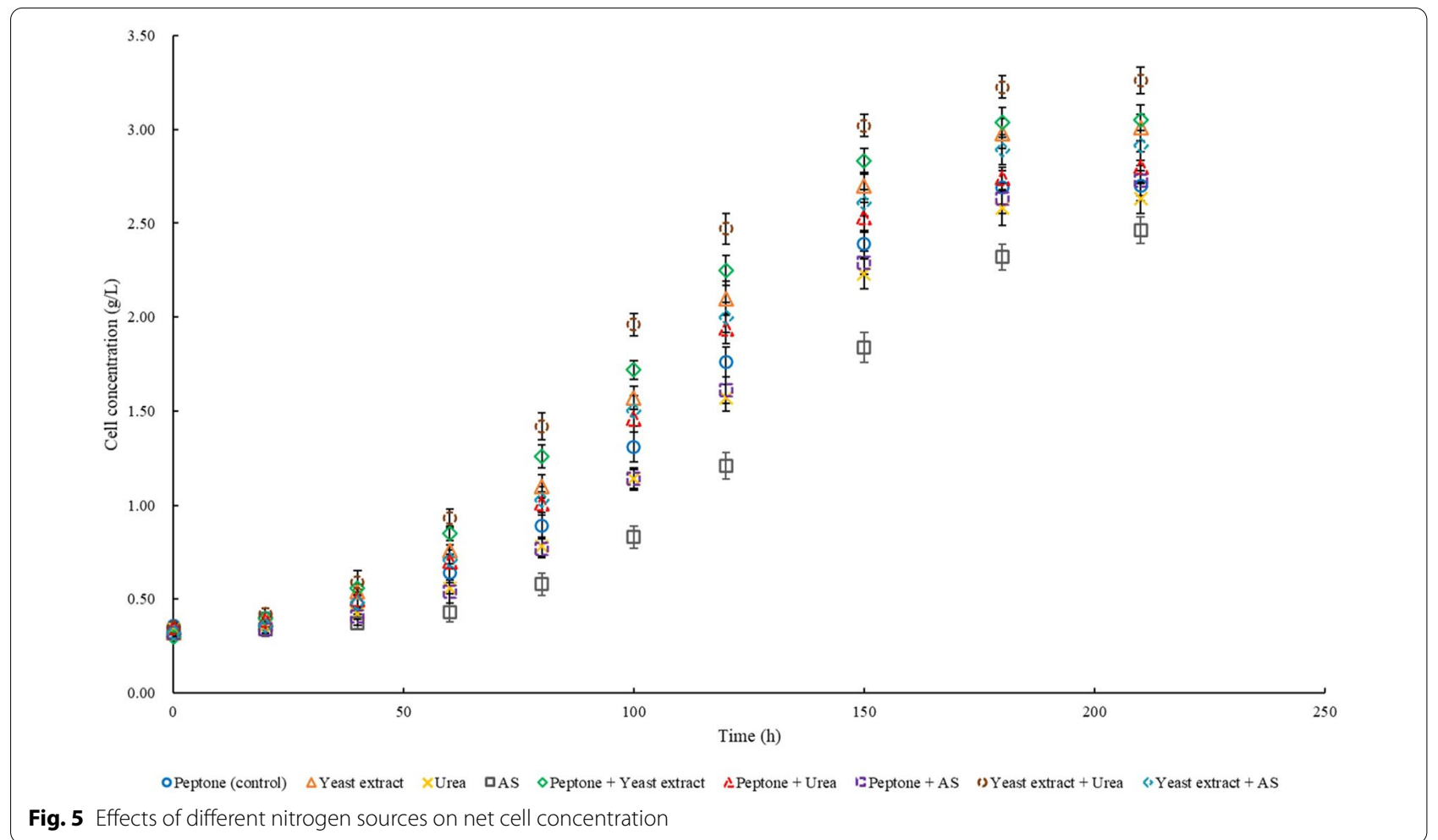

of inorganic nitrogen sources in the mixed nitrogen source can increase the synthesis and decomposition efficiency of PHB at the same time, thereby simultaneously increasing the production capacity of PHB and 3-HB (Wei et al. 2011).

\section{Conclusion}

Various sodium salts have a positive effect on the production of 3-HB and PHB at appropriate concentrations. Among them, the appropriate addition of $\mathrm{Na}_{3} \mathrm{C}_{6} \mathrm{H}_{5} \mathrm{O}_{7}$ can significantly promote the production of $3-\mathrm{HB}$ and $\mathrm{PHB}$ and reduce the synthesis of by-products, thereby effectively improving the conversion rate of carbon sources and the production efficiency of products. Sodium chloride is not conducive to the improvement of fermentation efficiency. Compared to a single nitrogen source, a mixed nitrogen source has greater advantages to produce 3-HB and PHB. This study focused on the effects of sodium salt-based anions and nitrogen sources as nutrients on the production of $3-\mathrm{HB}$ and $\mathrm{PHB}$. The results of this study can provide relevant support for the selection and further standardization of medium components for the production of 3-HB and PHB.

\section{Acknowledgements}

The authors thank SUNY College of Environmental Science and Forestry for the help and support in this study.

\section{Authors' contributions}

JW is responsible for conceptualization, methodology, writing (original draft) and investigation. $\mathrm{JH}$ is responsible for software, investigation, and writing (review and editing). SJ, HG, and JQ are responsible for investigation, validation, and formal analysis. XC, ZQ, and WC are responsible for resources and data curation. SL is responsible for writing (review and editing), supervision, project administration, and funding acquisition. JW, JH, SJ, HG, and SL are the primary contributors of this study. All authors read and approved the final manuscript.

\section{Funding}

This research did not receive any specific grant from funding agencies in the public, commercial, or not-for-profit sectors.

\section{Availability of data and materials}

The datasets used and/or analyzed during the current study are available from the corresponding author on reasonable request.

\section{Declarations}

Ethics approval and consent to participate

Not applicable.

\section{Consent for publication}

Not applicable.

\section{Competing interests}

The authors declare that they have no competing interests.

\section{Author details}

${ }^{1}$ Department of Chemical Engineering, SUNY College of Environmental Science and Forestry, Syracuse, NY 13210, USA. ${ }^{2}$ The Center for Biotechnology \& Interdisciplinary Studies (CBIS), Rensselaer Polytechnic Institute, Troy, NY 12180, USA. ${ }^{3}$ School of Engineering, Tufts University, Medford, MA 02155, USA. 
Received: 22 May 2021 Accepted: 13 July 2021

Published online: 19 July 2021

\section{References}

Alcântara JM, Distante F, Storti G, Moscatelli D, Morbidelli M, Sponchioni M (2020) Current trends in the production of biodegradable bioplastics: the case of polyhydroxyalkanoates. Biotechnol Adv 2:107582. https://doi.org/ 10.1016/j.biotechadv.2020.107582

Anjum A, Zuber M, Zia KM, Noreen A, Anjum MN, Tabasum S (2016) Microbial production of polyhydroxyalkanoates (PHAs) and its copolymers: a review of recent advancements. Int J Biol Macromol 89:161-174. https://doi.org/ 10.1016/j.jjbiomac.2016.04.069

Aramvash A, Moazzeni Zavareh F, Gholami Banadkuki N (2018) Comparison of different solvents for extraction of polyhydroxybutyrate from Cupriavidus necator. Eng Life Sci 18(1):20-28. https://doi.org/10.1002/elsc.201700102

Azizi N, Najafpour G, Younesi H (2017) Acid pretreatment and enzymatic saccharification of brown seaweed for polyhydroxybutyrate (PHB) production using Cupriavidus necator. Int J Biol Macromol 101:1029-1040. https://doi.org/10.1016/j.ijbiomac.2017.03.184

Bhatia SK, Shim YH, Jeon JM, Brigham CJ, Kim YH, Kim HJ, Seo HM, Lee JH, Kim JH, Yi DH, Lee YK (2015) Starch based polyhydroxybutyrate production in engineered Escherichia coli. Bioprocess Biosyst Eng 38(8):1479-1484. https://doi.org/10.1007/s00449-015-1390-y

Blevins HM, Blue MD, Cobbs BD, Ricotilli TA, Kyler SL, Shuey CT, Thompson WD, Baron SF (2018) Characterization of an extracellular polyhydroxyalkanoate depolymerase from streptomyces sp. SFB5A. J Bioremediat Biodegrad. https://doi.org/10.4172/2155-6199.1000452

Bomrungnok W, Arai T, Yoshihashi T, Sudesh K, Hatta T, Kosugi A (2020) Direct production of polyhydroxybutyrate from waste starch by newly-isolated Bacillus aryabhattai T34-N4. Environ Technol 41(25):3318-3328. https:// doi.org/10.1080/09593330.2019.1608314

Chen Y, Li S, Xiong J, Li Z, Bai J, Zhang L, Ye Q, Ouyang P, Ying H (2010) The mechanisms of citrate on regulating the distribution of carbon flux in the biosynthesis of uridine 5'-monophosphate by Saccharomyces cerevisiae. Appl Microbiol Biotechnol 86(1):75-81. https://doi.org/10.1007/ s00253-009-2287-y

Dalsasso RR, Pavan FA, Bordignon SE, de Aragão GM, Poletto P (2019) Polyhydroxybutyrate (PHB) production by Cupriavidus necator from sugarcane vinasse and molasses as mixed substrate. Process Biochem 85:12-18. https://doi.org/10.1016/j.procbio.2019.07.007

Dañez JC, Requiso PJ, Alfafara CG, Nayve FR Jr, Ventura JR (2020) Optimization of fermentation factors for polyhydroxybutyrate (PHB) production using Bacillus megaterium PNCM 1890 in simulated glucose-xylose hydrolysates from agricultural residues. Philipp J Sci 149(1):163-175

Dietrich D, Illman B, Crooks C (2013) Differential sensitivity of polyhydroxyalkanoate producing bacteria to fermentation inhibitors and comparison of polyhydroxybutyrate production from Burkholderia cepacia and Pseudomonas pseudoflava. BMC Res Notes 6(1):1-4. https://doi.org/10. 1186/1756-0500-6-219

Doi Y, Kawaguchi Y, Nakamura Y, Kunioka M (1989) Nuclear magnetic resonance studies of poly (3-hydroxybutyrate) and polyphosphate metabolism in Alcaligenes eutrophus. Appl Environ Microbiol 55(11):2932-2938. https://doi.org/10.1128/AEM.55.11.2932-2938.1989

El-Nahrawy S, El-Kodoos A, Rizk Y, Belal ES, El-Shouny W (2018) Production of poly- $\beta$-hydroxybutyrate (PHB) by Azotobacter sp. isolated from different sources. Environ Biodivers Soil Secur 2(8):183-192. https://doi.org/10. 21608/JENVBS.2019.6781.1044

Freches A, Lemos PC (2017) Microbial selection strategies for polyhydroxyalkanoates production from crude glycerol: effect of OLR and cycle length. New Biotechnol 39:22-28. https://doi.org/10.1016/j.nbt.2017.05.011

García A, Ferrer P, Albiol J, Castillo T, Segura D, Peña C (2018) Metabolic flux analysis and the NAD (P) H/NAD (P) + ratios in chemostat cultures of Azotobacter vinelandii. Microb Cell Fact 17(1):1-3. https://doi.org/10.1186/ s12934-018-0860-8

García G, Sosa-Hernández JE, Rodas-Zuluaga LI, Castillo-Zacarías C, lqbal H, Parra-Saldívar R (2021) Accumulation of PHA in the microalgae Scenedesmus sp. under nutrient-deficient conditions. Polymers 13(1):131. https:// doi.org/10.3390/polym13010131
Jan S, Roblot C, Courtois J, Courtois B, Barbotin JN, Seguin JP (1996) 1H NMR spectroscopic determination of poly 3-hydroxybutyrate extracted from microbial biomass. Enzyme Microb Technol 18(3):195-201. https://doi. org/10.1016/0141-0229(95)00096-8

Kessler B, Witholt B (2001) Factors involved in the regulatory network of polyhydroxyalkanoate metabolism. J Biotechnol 86(2):97-104. https://doi.org/ 10.1016/S0168-1656(00)00404-1

Kocharin K, Nielsen J (2013) Specific growth rate and substrate dependent polyhydroxybutyrate production in Saccharomyces cerevisiae. AMB Express 3(1):1-6. https://doi.org/10.1186/2191-0855-3-18

Koller M (2018) A review on established and emerging fermentation schemes for microbial production of Polyhydroxyalkanoate (PHA) biopolyesters. Fermentation 4(2):30. https://doi.org/10.3390/fermentation4020030

Lai YH, Lan JC (2021) Enhanced polyhydroxybutyrate production through incorporation of a hydrogen fuel cell and electro-fermentation system. Int J Hydrogen Energy 46(31):16787-16800. https://doi.org/10.1016/j. ijhydene.2020.08.117

Leong YK, Show PL, Lan JC, Krishnamoorthy R, Chu DT, Nagarajan D, Yen HW, Chang JS (2019) Application of thermo-separating aqueous two-phase system in extractive bioconversion of polyhydroxyalkanoates by Cupriavidus necator H16. Biores Technol 287:121474. https://doi.org/10.1016/j. biortech.2019.121474

Li M, Eskridge KM, Wilkins MR (2019) Optimization of polyhydroxybutyrate production by experimental design of combined ternary mixture (glucose, xylose and arabinose) and process variables (sugar concentration, molar C: N ratio). Bioprocess Biosyst Eng 42(9):1495-1506. https://doi.org/10. 1007/s00449-019-02146-1

Mohd Zain NF, Paramasivam M, Tan JS, Lim V, Lee CK (2021) Response surface methodology optimization of polyhydroxyalkanoate production by Burkholderia cepacia BPT1213 using waste glycerol from palm oil-based biodiesel production. Biotechnol Prog 37(1):e3077. https://doi.org/10. 1002/btpr.3077

Moreno P, Yañez C, Cardozo NS, Escalante H, Combariza MY, Guzman C (2015) Influence of nutritional and physicochemical variables on PHB production from raw glycerol obtained from a Colombian biodiesel plant by a wild-type Bacillus megaterium strain. New Biotechnol 32(6):682-689. https://doi.org/10.1016/j.nbt.2015.04.003

Park SH, Kim GB, Kim HU, Park SJ, Choi JI (2019) Enhanced production of poly3-hydroxybutyrate (PHB) by expression of response regulator DR1558 in recombinant Escherichia coli. Int J Biol Macromol 131:29-35. https://doi. org/10.1016/j.ijbiomac.2019.03.044

Pereira JR, Araújo D, Freitas P, Marques AC, Alves VD, Sevrin C, Grandfils C, Fortunato E, Reis MA, Freitas F (2021) Production of medium-chain-length polyhydroxyalkanoates by Pseudomonas chlororaphis subsp. aurantiaca: Cultivation on fruit pulp waste and polymer characterization. Int J Bio Macromol 167:85-92. https://doi.org/10.1016/j.ijbiomac.2020.11.162

Ramezani M, Amoozegar MA, Ventosa A (2015) Screening and comparative assay of poly-hydroxyalkanoates produced by bacteria isolated from the Gavkhooni Wetland in Iran and evaluation of poly- $\beta$-hydroxybutyrate production by halotolerant bacterium Oceanimonas sp. GK1. Ann Microbiol 65(1):517-526. https://doi.org/10.1007/s13213-014-0887-y

Ren Q, Ruth K, Thöny-Meyer L, Zinn M (2010) Enatiomerically pure hydroxycarboxylic acids: current approaches and future perspectives. Appl Microbiol Biotechnol 87(1):41-52. https://doi.org/10.1007/s00253-010-2530-6

Rodrigues PR, Nunes J, Lordelo LN, Druzian JI (2019) Assessment of polyhydroxyalkanoate synthesis in submerged cultivation of Cupriavidus necator and Burkholderia cepacia strains using soybean as substrate. Braz J Chem Eng 36(1):73-83. https://doi.org/10.1590/0104-6632.20190361s20170267

Rodríguez-Contreras A, Koller M, Braunegg G, Marqués-Calvo MS (2016) Poly [(R)-3-hydroxybutyrate] production under different salinity conditions by a novel Bacillus megaterium strain. New Biotechnol 33(1):73-77. https:// doi.org/10.1016/j.nbt.2015.08.006

Salgaonkar BB, Bragança JM (2017) Utilization of sugarcane bagasse by Halogeometricum borinquense strain E3 for biosynthesis of poly (3-hydroxybutyrate-co-3-hydroxyvalerate). Bioengineering 4(2):50. https://doi.org/ 10.3390/bioengineering4020050

Samantaray S, Mallick N (2012) Production and characterization of poly- $\beta$ hydroxybutyrate (PHB) polymer from Aulosira fertilissima. J Appl Phycol 24(4):803-814. https://doi.org/10.1007/s10811-011-9699-7 
Sharma V, Misra S, Srivastava AK (2017) Developing a green and sustainable process for enhanced PHB production by Azohydromonas australica. Biocatal Agric Biotechnol. https://doi.org/10.1016/j.bcab.2017.02.014

Sirohi R, Gaur VK, Pandey AK, Sim SJ, Kumar S (2021) Harnessing fruit waste for poly-3-hydroxybutyrate production: a review. Biores Technol. https://doi. org/10.1016/j.biortech.2021.124734

Thapa C, Shakya P, Shrestha R, Pal S, Manandhar P (2018) Isolation of polyhydroxybutyrate (PHB) producing bacteria, optimization of culture conditions for PHB production, extraction and characterization of PHB. Nepal J Biotechnol 6(1):62-68. https://doi.org/10.3126/njb.v6i1.22339

Uchino K, Saito T, Gebauer B, Jendrossek D (2007) Isolated poly (3-hydroxybutyrate) (PHB) granules are complex bacterial organelles catalyzing formation of PHB from acetyl coenzyme $A(C O A)$ and degradation of PHB to acetyl-CoA. J Bacteriol 189(22):8250-8256. https://doi.org/10.1128/JB. 00752-07

Wang Y, Liu S (2014) Production of (R)-3-hydroxybutyric acid by Burkholderia cepacia from wood extract hydrolysates. AMB Express 4(1):1. https://doi. org/10.1186/s13568-014-0028-9

Wang P, Qiu YQ, Chen XT, Liang XF, Ren LH (2019) Metabolomic insights into polyhydroxyalkanoates production by halophilic bacteria with acetic acid as carbon source. Biosci Biotechnol Biochem 83(10):1955-1963. https:// doi.org/10.1080/09168451.2019.1630252
Wang J, Huang J, Jiang S, Zhang J, Zhang Q, Ning Y, Fang M, Liu S (2020) Parametric optimization and kinetic study of I-lactic acid production by homologous batch fermentation of Lactobacillus pentosus cells. Biotechnol Appl Biochem. https://doi.org/10.1002/bab.1994

Wei YH, Chen WC, Wu HS, Janarthanan OM (2011) Biodegradable and biocompatible biomaterial, polyhydroxybutyrate, produced by an indigenous Vibrio sp. BM-1 isolated from marine environment. Mar Drugs 9(4):615624. https://doi.org/10.3390/md9040615

Wood JM (2015) Bacterial responses to osmotic challenges. J Gen Physiol 145(5):381-388. https://doi.org/10.1085/jgp.201411296

Yadav J, Balabantaray S, Patra N (2017) Statistical optimization of fermentation conditions for the improved production of poly- $\beta$-hydroxybutyrate from Bacillus subtilis. Chem Eng Commun 204(10):1122-1128. https://doi.org/ 10.1080/00986445.2017.1347094

\section{Publisher's Note}

Springer Nature remains neutral with regard to jurisdictional claims in published maps and institutional affiliations.

\section{Submit your manuscript to a SpringerOpen ${ }^{\circ}$ journal and benefit from:}

- Convenient online submission

- Rigorous peer review

- Open access: articles freely available online

- High visibility within the field

- Retaining the copyright to your article

Submit your next manuscript at $\boldsymbol{\nabla}$ springeropen.com 